\title{
Dampak alokasi belanja langsung terhadap ketimpangan ekonomi wilayah (Studi kasus Provinsi Sumatera Utara, Provinsi Jambi, dan Provinsi Bengkulu)
}

\author{
Alberd Kurniawan Gulo, Zamzami*, dan Adi Bhakti \\ Prodi Ekonomi Pembangunan, Fakultas Ekonomi dan Bisnis, Universitas Jambi \\ *E-mail korespondensi:zamzami@unja.ac.id
}

\begin{abstract}
This study aims to analyze: 1) the development of direct shopping; 2) developments in economic inequality; 3 ) the effect of direct spending on economic inequality. This study uses time series data from 2005-2014 with a case study of North Sumatra Province, Jambi Province, and Bengkulu Province. The study found that 1) North Sumatra Province had the highest direct expenditure development from Jambi Province and Bengkulu Province; 2) North Sumatra Province which has the highest direct expenditure also has higher inequality from Jambi Province and Bengkulu Province but still falls into low inequality; 3) Direct expenditure has a significant effect on economic inequality in North Sumatra and Bengkulu Provinces, while in Jambi Province direct expenditure does not significantly influence economic inequality.
\end{abstract}

Keywords: Direct Expenditure, Economic Inequality, GDP, Population Growth

\begin{abstract}
Abstrak.
Penelitian ini bertujuan untuk menganalisis: 1) perkembangan belanja langsung; 2) perkembangan ketimpangan ekonomi; 3) pengaruh belanja langsung terhadap ketimpangan ekonomi. Penelitian ini menggunakan data runtun waktu tahun 2005-2014 dengan studi kasus Provinsi Sumatera Utara, Provinsi Jambi, dan Provinsi Bengkulu. Penelitian menemukan bahwa 1) Provinsi Sumatera Utara memiliki perkembangan belanja langsung tertinggi dari Provinsi Jambi dan Provinsi Bengkulu; 2) Provinsi Sumatera Utara yang memiliki belanja langsung tertinggi juga memiliki ketimpangan yang lebih tinggi dari Provinsi Jambi dan Provinsi Bengkulu namun masih masuk dalam ketimpangan rendah; 3) Belanja langsung berpengaruh signifikan terhadap ketimpangan ekonomi di Provinsi Sumatera Utara dan Provinsi Bengkulu, sedangkan di Provinsi Jambi belanja langsung tidak berpengaruh signifikan terhadap ketimpangan ekonomi.
\end{abstract}

Kata Kunci : belanja langsung, ketimpangan ekonomi, PDRB, pertumbuhan penduduk.

\section{PENDAHULUAN}

Otonomi daerah merupakan bentuk awal kemandirian suatu daerah di Indonesia. Otonomi daerah muncul sebagai sistem untuk memperbaiki bentuk sistem pemerintahan pada masa orde baru yang bersifat sentralisasi. Undang-undang No.32 Tahun 2004 tentang Pemerintah Daerah adalah salah satu landasan yuridis bagi pengembangan otonomi daerah di Indonesia. Dalam undang-undang ini disebutkan bahwa pengembangan otonomi pada daerah kabupaten dan kota diselenggarakan dengan memperhatikan prinsip-prinsip demokrasi, peran serta masyarakat, pemerataan, dan keadilan, serta memperhatikan potensi dan keanekaragaman daerah. Undang-undang ini memberikan otonomi secara utuh kepada daerah kabupaten dan kota untuk membentuk dan melaksanakan kebijakan menurut prakarsa dan aspirasi masyarakatnya. Sekarang daerah sudah diberi kewenangan yang utuh dan bulat untuk merencanakan, 
melaksanakan, mengawasi, mengendalikan dan mengevaluasi kebijakan-kebijakan daerah.

Otonomi yang diberikan kepada kota dilaksanakan dengan memberikan kewenangan yang luas, nyata dan bertanggung jawab kepada pemerintah daerah secara proporsional. Pelimpahan tanggungjawab akan diikuti oleh pengaturan pembagian, dan pemanfaatan sumberdaya nasional yang berkeadilan, serta perimbangan keuangan pusat dan daerah. Dengan demikian Pemerintah daerah diharapkan lebih mengerti dan memenuhi aspirasi masyarakat di daerahnya, agar dapat mendorong timbulnya prakarsa dan partisipasi aktif masyarakat dalam menyelenggarakan pemerintahan dan pelaksanaan pembangunan yang merupakan prasyarat keberhasilan pelaksanaan pemerintahan.

Dengan dasar undang-undang yang memberikan otonomi secara utuh kepada Pemerintah Daerah untuk membentuk dan melaksanakan kebijakan menurut prakarsa dan aspirasi masyarakatnya, untuk merencanakan, melaksanakan, mengawasi, mengendalikan, dan mengevaluasi kebijakan-kebijakan otonomi daerah yang diberikan kepada Pemerintah Daerah dilaksanakan dengan memberikan yang luas, nyata, dan bertanggung jawab kepada pemerintah daerah secara proporsional.Pelimpahan tanggung jawab akan diikuti oleh pengaturan pembagian dan pemanfaatan sumber daya nasional yang berkeadilan, serta perimbangan keuangan pusat dan daerah. Dengan demikian Pemerintah Daerah diharapkan lebih mengerti dan memenuhi aspirasi masyarakat di daerahnya, agar dapat mendorong timbulnya prakarsa dan partisipasi aktif masyarakat dalam menyelenggarakan pemerintahan dan pelaksanaan pembangunan yang merupakan prasyarat keberhasilan pelaksanaan pemerintahan.

Keberhasilan pelaksanaan pemerintah dapat diukur juga dengan melihat kemandirian keuangan. Kemandirian keuangan menjadi hal yang sangat penting bagi daerah terutama terkait dengan sumbangan keuangan daerah terhadap pertumbuhan ekonomi daerah itu sendiri. Besarnya kontribusi pengeluaran pemerintah daerah terhadap pertumbuhan ekonomi daerah seharusnya merupakan sebuah peluang yang dapat dimanfaatkan secara optimal untuk mendorong perekonomian daerah.Dana untuk pembiayaan pembangunan daerah diupayakan bersumber dari kemampuan keuangan daerah sendiri untuk memacu peningkatan kemandirian daerah dalam pelaksanaan pembangunan. Dengan kata lain pemerintah daerah dipacu untuk meningkatkan kemampuan seoptimal mungkin di dalam mendanai penyelenggaraan pemerintahan dan pelayanan publik dengan cara menggali segala sumber dana potensial yang ada di daerah tersebut.

Bukan hanya taktis dalam mencari dana dalam pemenuhan program-program, pemerintah daerah juga harus bijak dalam pemakaian uang daerah dalam alokasi belanja daerah. Pemerintah daerah sebaiknya seimbang dalam penggunaan antara belanja langsung dan belanja tidak langsung.Hingga saat ini, otonomi daerah di masing-masing provinsi di Sumatera cukup berkembang dengan baik. Beberapa Provinsi di Sumatera berkembang dengan pesat tidak kalah dengan provinsi yang ada di Pulau Jawa. Hal ini ditandai dengan besarnya pengeluaran pemerintah daerah dalam mendanai proyekproyek demi kepentingan masyarakat daerahnya. Dari data realisasi belanja langsung, Provinsi Sumatera Utara merealisasikan belanja langsung sebesar 2.819 miliar untuk mendukung kegiatan kepemerintahannya. Realisasi belanja langsung pada tahun 2014 tersebut merupakan salah satu realisasi terbesar dari sepuluh provinsi yang ada di Pulau Sumatera. Kemudian jika kita lihat Provinsi Jambi merealisasikan belanja langsung sebesar 1.842 miliar, berbanding terbalik dengan Provinsi Bengkulu dimana belanja 
langsung direalisasikan sebesar 1.028 miliar. Pada tahun 2014 tersebut merupakan salah satu realisasi terkecil dari sepuluh provinsi yang ada di Pulau Sumatera.

Berdasarkan latar belakang tersebut, penelitian ini bertujuan untuk menganlisis: 1) belanja langsung Provinsi Sumatera Utara, Provinsi Jambi, dan Provinsi Bengkulu pada tahun 2005-2014.(2) ketimpangan ekonomi Provinsi Sumatera Utara, Provinsi Jambi, dan Provinsi Bengkulu pada tahun 2005-2014, (3) pengaruh alokasi belanja langsung terhadap ketimpangan ekonomi Provinsi Sumatera Utara, Provinsi Jambi, dan Provinsi Bengkulu.

\section{TINJAUAN PUSTAKA}

Menurut Guritno (1999), pengeluaran pemerintah mencerminkan kebijakan pemerintah. Apabila pemerintah telah menetapkan suatu kebijakan untuk membeli barang dan jasa, pengeluaran pemerintah mencerminkan biaya yang harus dikeluarkan oleh pemerintah untuk melaksanakan kebijakan tersebut. Teori mengenai perkembangan pengeluaran pemerintah dikemukakan juga oleh para ahli ekonomi,yaitu model pembangunan tentang perkembangan pengeluaran pemerintah, dan mengenai perkembangan aktivitas pemerintah.

Musgrave dan Rostow menyatakan perkembangan pengeluaran negara sejalan dengan tahap perkembangan ekonomi dari suatu negara. Menurut Musgrave (1980) bahwa dalam suatu proses pembangunan, investasi swasta dalam presentase terhadap PDB semakin besar dan presentase investasi pemerintah terhadap PDB akan semakin kecil. Pada tahap awal perkembangan ekonomi diperlukan pengeluaran negara yang besar untuk investasi pemerintah, utamanya untuk menyediakan infrastruktur seperti sarana jalan, kesehatan, pendidikan, dan fasilitas umum lainnya. Pada tahap menengah pembangunan ekonomi, investasi tetap diperlukan untuk pertumbuhan ekonomi, namun diharapkan investasi sektor swasta sudah mulai berkembang. Pada tahap lanjut pembangunan ekonomi, pengeluaran pemerintah tetap diperlukan, utamanya untuk meningkatkan kesejahteraan masyarakat.Menurut Sukirno (2004), pertumbuhan ekonomi adalah perkembangan kegiatan dalam perekonomian yang menyebabkan barang dan jasa yang diproduksikan dalam masyarakat bertambah dan kemakmuran masyarakat meningkat. Ukuran yang sering di gunakan dalam menghitung pertumbuhan ekonomi adalah Produk Domestik Bruto (PDB).

Wagner menyatakan berdasarkan pengamatan dari negara-negara maju, disimpulkan bahwa dalam perekonomian suatu negara, pengeluaran pemerintah akan meningkat sejalan dengan peningkatan pendapatan perkapita negara tersebut. Di negaranegara maju, kegagalan pasar bisa saja terjadi menimpa industri-industri tertentu dari negara tersebut. Kegagalan dari suatu industri dapat saja merembet ke industri lain yang saling terkait. Di sini diperlukan peran pemerintah untuk mengatur hubungan antara masyarakat, industri, hukum, danpendidikan.

Menurut Menteri Negara Otonomi Daerah RI dan PAU-SE UGM, APBD pada hakikatnya merupakan instrumen kebijakan yang dipakai sebagai alat untuk meningkatkan pelayanan umum dan kesejahteraan masyarakat di daerah. Oleh kerena itu, DPRD dan pemerintah daerah harus selalu berupaya secara nyata dan terstruktur untuk menghasilkan suatu APBD yang dapat mencerminkan kebutuhan riil masyarakat atas dasar potensi masing-masing daerah serta dapat memenuhi tuntuta $\mathrm{n}$ terciptanya anggaran daerah yang berorientasikan kepentingan dan akuntabilitas publik. Suatu anggaran yang telah direncanakan dengan baik, sehingga baik tujuan maupun sasaran akan dapat tercapai secara berdayaguna dan berhasil guna. 
Sementara itu Mardiasmo (2002:11) mengatakan, bahwa salah satu aspek penting dari pemerintah daerah yang harus diatur secara hati-hati adalah masalah pengelolaan keuangan dan anggaran daerah. Anggaran daerah yang tercermin dalam APBD merupakan instrumen kebijakan utama bagi pemerintah daerah, menduduki porsi sentral dalam upaya pengembangan kapabilitas dan efektivitas pemerintah daerah. Anggaran daerah seharusnya digunakan sebagai alat untuk menentukan besarnya pendapatan dan belanja, alat bantu pengambilan putusan dan perencanaan pembangunan serta alat otoritas pengeluaran di masa yang akan datang dan ukuran standar untuk mengevaluasi kinerja serta alat koordinasi bagi smeua aktivitas pada berbagai unit kerja.Penyusunan APBD merupakan hal yang sangat penting dalam rangka penyelenggaraan fungsi daerah. Oleh karena itu, haruslah disusun dan dipertimbangkan dengan seksama yang dalam pelaksanaannya haruslah sesuai dengan sasaran yang telah ditetapkan. Menurut Abdul Halim, dalam bukunya “ Akuntansi Sektor Publik Akuntansi Keuangan Daerah”, menyatakan bahwa APBD adalah "Rencana kegiatan pemerintah daerah yang dituangkan dalam bentuk angka dan menunjukan adanya sumber penerimaan yang merupakan target minimal dan biaya yang merupakan target maksimal untuk suatu periode anggaran"(2004).

Belanja langsung, yaitu belanja yang dipengaruhi secara langsung oleh adanya program dan kegiatan yang direncanakan. Keberadaan anggaran belanja langsung merupakan konsekuensi karena adanya program atau kegiatan. Karakteristik belanja langsung adalah bahwa input (alokasi belanja) yang ditetapkan dapat diukur dan diperbandingkan dengan output yang dihasilkan. Varian jumlah komponen belanja langsung sebagian besar dipengaruhi oleh target kinerja atau tingkat pencapaian program atau kegiatan yang diharapkan.

Salah satu tujuan pembangunan ekonomi daerah adalah untuk mengurangi ketimpangan (disparity). Peningkatan pendapatan per kapita memang menunjukkan tingkat kemajuan perekonomian suatu daerah. Namun meningkatnya pendapatan per kapita tidak selamanya menunjukkan bahwa distribusi pendapatan lebih merata. Seringkali di negara-negara berkembang dalam perekonomiannya lebih menekankan penggunaan modal dari pada tenaga kerja sehingga keuntungan dari perekonomian tersebut hanya dinikmati sebagian masyarakat saja. Apabila ternyata pendapatan nasional tidak dinikmati secara merata oleh seluruh lapisan masyarakat, maka dapat dikatakan bahwa telah terjadi ketimpangan.

Todaro (2004), menggambarkan ketimpangan dengan mempertimbangkan hubungan antara tingkat pendapatan perkapita dan tingkat ketimpangan pendapatan untuk Negara maju dan sedang berkembang. Dan menggambarkan ketimpangan pendapatan Negaranegara tersebut dalam tiga kelompok dimana pengelompokan ini disesuaikan dengan tinggi, sedang dan rendahnya tingkat pendapatan yang diukur menurut koefisien gini dan tingkat PDRB.

Jeffrey G. Williamson (1965) meneliti hubungan antara disparitas regional dengan tingkat pembangunan ekonomi, dengan menggunakan data ekonomi negara yang sudah maju dan yang sedang berkembang. Ditemukan bahwa selama tahap awal pembangunan, disparitas regional menjadi lebih besar dan pembangunan terkonsentrasi di daerah-daerah tertentu. Williamson menggunakan Williamson Index untuk mengukur ketimpangan pembangunan antar wilayah. Indeks Williamson menggunakan PDRB per kapita sebagai data dasar. Alasannya jelas bahwa yang diperbandingkan adalah tingkat pembangunan antar wilayah bukan tingkat kesejahteraan antar kelompok.

Untuk mengembangkan daerahnya, pemerintah daerah diberi wewenang untuk mengelola atau mengatur keuangan daerahnya sendiri-sendiri. Pengeluaran terbesar dari 
pemerintah daerah sendiri diutamakan bagi pendidikan dasar, menengah, dan kejuruan. Pemerintah daerah menyelenggarakan pendidikan dasar dan menengah mencerminkan manfaat adanya anggaran daerah. Dengan tenaga kerja yang terdidik maka akan menaikkan produktivitas suatu perekonomian.

Pengeluaran pemerintah daerah merupakan alat intervensi pemerintah daerah terhadap perekonomian yang dianggap paling efektif. Tingkat efektifitas pengeluaran daerah dapat diukur melalui seberapa besar pertumbuhan ekonomi yang dapat dicapai. Hal ini disebabkan karena pengeluaran daerah lebih berkaitan erat dengan Anggaran Pendapatan dan Belanja Daerah (APBD), dimana secara langsung akan mempengaruhi penerimaan daerah dan pembiayaan-pembiayaan daerah, sehingga akan mempengaruhi pertumbuhan ekonomi secara langsung. Lalu secara tidak langsung pertumbuhan ekonomi yang dirasakan akan menimbulkan ketimpangan karena berbagai faktor. Pengambilan keputusan dalam alokasi anggaran belanja daerah mempengaruhi besar ketimpangan, karena daerah yang dapat mengalokasikan pada belanja langsung atau yang bersifat investasi cenderung pertumbuhan ekonominya lebih cepat dari daerah yang alokasi belanja langsungnya sedikit.

\section{METODOLOGI PENELITIAN}

\section{Jenis dan sumber data}

Jenis data yang digunakan dalam penelitian ini adalah data sekunder dalam periode Tahun 2005 - 2014, mencakup data belanja langsung, PDRB dan pertumbuhan penduduk. Sumber data utama dalah dari Badan Pusat Statistik (BPS) dan Kementrian Keuangan.

\section{Metode analisis dan pengolahan data}

Pengolahan data dalam penelitian ini menggunakan program EViews7. Metode analisis yang digunakan dalam penelitian ini adalah analisis deskriptif dan analisis kuantitatif. Dalam penulisan penelitian ini, model yang digunakan yaitu model regresi sederhana.Untuk menganalisis ketimpangan pembangunan ekonomi antara Provinsi Sumatera Utara, Provinsi Jambi dan Provinsi Bengkulu maka digunakan analisis indeks Williamson dengan formula sebagai berikut :

$$
\text { Williamson Index }(\mathrm{Vw})=\frac{\sqrt{\sum_{\mathrm{i}=1}^{\mathrm{n}}(\mathrm{yi}-\mathrm{y})^{2}-\left(\frac{\mathrm{fi}}{\mathrm{n}}\right)}}{\mathrm{Y}}
$$

Keterangan :

$\mathrm{Vw} \quad=$ Indeks Williamson

yi $\quad=$ PDRB per kapita daerah $\mathrm{i}$

$\mathrm{y} \quad=$ PDRB per kapita rata-rata seluruh daerah

fi $\quad=$ Jumlah penduduk daerah $\mathrm{i}$

$\mathrm{n} \quad=$ Jumlah penduduk seluruh daerah

Untuk mengukur Ketimpangan pembangunan ekonomi wilayah indeks Williamson (Vw) berkisar antara 0-1 :

- Bila $V_{w} 0<0,3$ artinya, ketimpangan pembangunan ekonomi wilayah rendah.

- Bila $V_{w} 0<0,4$ artinya, ketimpangan pembangunan ekonomi wilayah sedang.

- Bila Vw 0>0,4 artinya, ketimpangan pembangunan ekonomi wilayah tinggi atau tidak merata. 
Untuk menganalisis dampak alokasi belanja langsung terhadap ketimpangan ekonomi wilayah pada masing-masing provinsi (Sumatera Utara, Jambi dan Bengkulu) digunakan model regresi sederhana dengan persamaan sebagai berikut:

$K E_{t}=\beta_{0}+\beta_{1} B L_{t}+e_{t}$

Dimana:

$\mathrm{KE}=$ ketimpangan ekonomi

$\mathrm{BL}=$ belanja langsung

$\mathrm{B} 0, \beta 1=$ koefisien regresi

ei $=$ error term

\section{Definisi Operasional Variabel}

1. Belanja Langsung : Tingkat belanja lansung tahunan Indonesia yang diukur dalam satuan miliar rupiah pada periode 2005-2014.

2. Ketimpangan Ekonomi : merupakan hasil olah data dari PDRB dan jumlah penduduk periode 1996-2014 dalam satuan persen.

\section{HASIL DAN PEMBAHASAN}

\section{Perkembangan belanja langsung di wilayah Sumatera (Provinsi Sumatera Utara, Provinsi Jambi, dan Provinsi Bengkulu.}

Perkembangan belanja langsung Provinsi Sumatera Utara, Provinsi Jambi, dan Provinsi Bengkulu berfluktuasi. Jika diamati, Provinsi Sumatera Utara memiliki laju tertinggi pada tahun 2011 sebesar 35,6 persen, untuk Provinsi Jambi memiliki laju tertinggi pada tahun 2013 sebesar 35,2 persen dan untuk Provinsi Bengkulu memiliki laju tertinggi pada tahun 2008 sebesar 139,6 persen. Pada tahun 2006 perkembangan belanja langsung dari tahun sebelumnya yaitu 16,3 persen. Pada tahun 2007 mengalami keaikan realisasi belanja langsung sebesar 18,1 persen. Kemudian pada tahun 2008 mengalami penurunan realisasi belanja langsung sebesar -2,3 persen. Berbeda dari tahun sebelumnya, pada tahun 2009 mengalami kenaikan sebesar 17,5 persen. Kemudian pada tahun 2010 dan 2011 belanja langsung Provinsi Sumatera Utara terus mengalami kenaikan sebesar 21,5 persen dan 35,6 persen. Pada tahun 2011 ini merupakan puncak perkembangan belanja langsung tertinggi selama tahun penelitian. Pada tahun 2012, belanja langsung Provinsi Sumatera Utara mengalami kenaikan sebesar 8,9 persen. Pada tahun 2013, belanja langsung Provinsi Sumatera Utara mengalami penurunan sebesar 8,8 persen. Kemudian pada tahun 2014 mengalami kenaikan sebesar 24,9 persen. Rata-rata perkembangan belanja langsung Provinsi Sumatera Utara adalah 11 persen.

Selanjutnya jika diamati perkembangan belanja langsung Provinsi Jambi selama tahun penelitian berfluktuasi, pada tahun 2006 mengalami kenaikan laju belanja langsung sebesar 18,2 persen. Pada tahun 2007 mengalami kenaikan realisasi belanja langsung sebesar 16,6 persen. Pada tahun 2008 mengalami kenaikan realisasi belanja langsung sebesar 14,7 persen. Berbeda pada tahun sebelumnya, pada tahun 2009 dan 2010 mengalami penurunan realisasi belanja langsung sebesar 5,41 persen dan 3,43 persen. Namun setelah itu realisasi belanja langsung Provinsi Jambi terus mengalami kenaikan dari tahun 2011 sampai tahun 2014. Pada tahun 2011 realisasi belanja langsung naik sebesar 21,3 persen. Kemudian tahun 2012 naik sebesar 29,9 persen. Pada tahun 2013 realisasi belanja langsung Provinsi Jambi naik 35,2 persen menjadi, pada tahun ini merupakan perkembangan realisasi belanja langsung terbesar Provinsi Jambi selama tahun penelitian. Dan pada tahun 2014 realisasi belanja langsung Provinsi 
Jambi naik sebesar 5,9 persen. Rata-rata perkembangan belanja langsung Provinsi Jambi adalah 14,77 persen.

Tabel 1. Perkembangan realisasi belanja langsung Provinsi Sumatera Utara, Jambi dan Bengkulu periode 2005-2014

\begin{tabular}{|crrr}
\hline Tahun & Sumatera Utara & Jambi & Bengkulu \\
\hline 2005 & - & - & - \\
2006 & $-16,3$ & 18,2 & 37,3 \\
2007 & 18,1 & 16,6 & 28,5 \\
2008 & $-2,3$ & 14,7 & 139,6 \\
2009 & 17,5 & $-5,41$ & $-42,1$ \\
2010 & 21,5 & $-3,43$ & $-16,6$ \\
2011 & 35,6 & 21,3 & 14,5 \\
2012 & 8,9 & 29,9 & 42,1 \\
2013 & $-8,8$ & 35,2 & 27,3 \\
2014 & 24,9 & 5,9 & 10,4 \\
\hline Rata-rata & 11,01 & 14,77 & 26,77 \\
\hline
\end{tabular}

Selanjutnya jika kita amati realisasi belanja langsung Provinsi Bengkulu, pada tahun 2006 memiliki laju perkembangan belanja langsung sebesar 37,3 persen. Kemudian pada tahun 2007 realisasi belanja langsung Provinsi Bengkulu naik sebesar 28,5 persen. Pada tahun 2008 laju perkembangan realisasi belanja langsung merupakan perkembangan yang tertinggi yaitu 139,6 persen menjadi. Namun pada dua tahun setelah itu mengalami penurunan perkembangan dimana pada tahun 2009 menurun sebesar 42,1 persen dan pada tahun 2010 menurun kembali sebesar 16,6 persen. Kemudian laju perkembangan belanja langsung Provinsi Bengkulu berangsur baik dimana pada tahun 2011 mulai naik sebesar 14,5 persen,kemudian tahun 2012 sebesar 42,1 persen, setelah itu pada tahun 2013 naik sebesar 27,3 persen dan pada tahun 2014 naik sebesar 10,4 persen.Rata-rata perkembangan belanja langsung Provinsi Bengkulu adalah 26,77 persen.

\section{Ketimpangan ekonomi di wilayah Sumatera (Provinsi Sumatera Utara, Provinsi Jambi, dan Provinsi Bengkulu.}

Pada tahun 2005-2014, Provinsi Sumatera Utara memiliki nilai ketimpangan pembangunan ekonomi terhadap ketimpangan pembangunan ekonomi tiga provinsi di wilayah sumatera sebesar 0,28-0,38 dengan rata-rata nilai ketimpangan pembangunan ekonomi sebesar 0,305. Dari angka tersebut dapat kita analisis Provinsi Sumatera Utara memiliki Indeks ketimpangan pembangunan ekonomi tiga provinsi di wilayah sumatera berada pada ketimpangan yang sedang. Hal ini dikarenakan rata-rata PDRB perkapita Provinsi Sumatera Utara Rp 9.475 dan jumlah penduduk tahun 2010 adalah 12,98 juta jiwa serta struktur perekonomian Provinsi Sumatera Utara didominasi oleh sektor pertanian dan perkebunan yang beberapa bagian sudah dilakukan dengan cara modern namun dibagian daerah lainnya masih menggunakan cara tradisional. Selain itu pada beberapa daerah Provinsi Sumatera Utara terdapat tambang gas alam sedangkan daerah lain hanya mengandalkan pertanian.

Ketimpangan pembangunan ekonomi terhadap indeks ketimpangan pembangunan ekonomi Provinsi Jambi di tiga provinsi di wilayah sumatera sebesar0,03-0,057 dengan rata-rata sebesar 0,04. Nilai ketimpangan pembangunan ekonomi di Provinsi Jambi mempunyai indeks ketimpangan berada pada ketimpangan yang rendah. Dikarenakan rata-rata PDRB perkapita Rp 6.294 dan mempunyai jumlah penduduk tahun 2010 
adalah 3,09 juta jiwa dimana struktur perekonomian Provinsi Jambi didominasi dengan pertanian dan perkebunan yang masih menggunakan cara tradisional dengan tingkat pendapatan yang dihasilkan masih relatif rendah.

Tabel 2. Ketimpangan Ekonomi (Indeks Williamson) Provinsi Sumatera Utara, Jambi dan Bengkulu periode 2005-2014

\begin{tabular}{cccr}
\hline Tahun & Sumatera Utara & Jambi & Bengkulu \\
\hline 2005 & 0.283 & 0.031 & 0.076 \\
2006 & 0.284 & 0.032 & 0.076 \\
2007 & 0.286 & 0.031 & 0.077 \\
2008 & 0.285 & 0.029 & 0.078 \\
2009 & 0.279 & 0.026 & 0.078 \\
2010 & 0.338 & 0.057 & 0.08 \\
2011 & 0.332 & 0.053 & 0.082 \\
2012 & 0.327 & 0.05 & 0.082 \\
2013 & 0.321 & 0.046 & 0.083 \\
2014 & 0.319 & 0.043 & 0.084 \\
\hline Rata-rata & 0.305 & 0.04 & 0.08 \\
\hline
\end{tabular}

Selanjutnya Provinsi Bengkulu memiliki indeks ketimpangan pembangunan ekonomi di tiga provinsi di wilayah sumatera dari tahun 2005-2014 sebesar 0.076 0,084 dengan rata-rata sebesar 0,8. Ketimpangan pembangunan ekonomi Provinsi Bengkulu terhadap indeks ketimpangan pembangunan ekonomi berada pada ketimpangan yang rendah. Rata-rata PDRB perkapita Provinsi Bengkulu adalah Rp 5.179 dan jumlah penduduk tahun 2010 adalah 1,71 juta jiwa dan perekonomian Provinsi Bengkulu didominasi oleh sektor pertanian yang masih menggunakan cara tradisional sehingga pendapatan yang relatif rendah. Selain itu Provinsi Bengkulu memiliki pendapatan di sektor pariwisata.

\section{Pengaruh Belanja Langsung Terhadap Ketimpangan Ekonomi Wilayah}

\section{Provinsi Sumatera Utara}

Hasil estimasi model pengaruh belanja langsung terhadap ketimpangan ekonomi wilayah di Provinsi Sumatera Utara diberikan sebagai berikut:

$\begin{array}{lll}\mathrm{KE} & =1.939- & 0.1546 * \mathrm{BL} \\ \mathrm{t}-\mathrm{stat} & =(5.479) & (-4.019) \\ \text { Prob. } & =(0.0006) & (0.0038) \\ \mathrm{R}^{2} & =0.6688 & \end{array}$

Dari persamaan tersebut diketahui nilai R-Squared model adalah sebesar 0,6688. Ini berarti variasi perubahan (naik atau turunnya) belanja langsung mempengaruhi ketimpangan ekonomi sebesar $66,88 \%$, sedangkan sisanya $(33,12 \%)$ dipengaruhi oleh variabel lain yang tidak dimasukkan dalam penelitian. Probabilitas t sebesar 0.0038 $<0,01$ yang menunjukkan adannya pengaruh yang signifikan antara alokasi belanja langsung terhadap ketimpangan ekonomi wilayah di Provinsi Sumatera Utara.

\section{Provinsi Jambi}

Hasil estimasi model pengaruh belanja langsung terhadap ketimpangan ekonomi wilayah di Provinsi Jambi diberikan sebagai berikut: 


$$
\begin{array}{lll}
\mathrm{KE} & =4.5896 & -0.3530 * \mathrm{BL} \\
\mathrm{t}-\mathrm{stat} & =(2.268) & (-1.5681) \\
\text { Prob. } & =(0.0530) & (0.1555) \\
\mathrm{R}^{2} & =0.2351 &
\end{array}
$$

Dari persamaan tersebut diketahui nilai R-Squared model adalah sebesar 0,2351. Ini berarti variasi perubahan (naik atau turunnya) belanja langsung mempengaruhi ketimpangan ekonomi sebesar $23,51 \%$, sedangkan sisanya $(76,49 \%)$ dipengaruhi oleh variabel lain yang tidak dimasukkan dalam penelitian. Probabilitas t sebesar 0.1555 $>0,11$ yang menunjukkan tidak adanya pengaruh yang signifikan antara alokasi belanja langsung terhadap ketimpangan ekonomi wilayah di Provinsi Jambi.

\section{Provinsi Bengkulu}

Hasil estimasi model pengaruh belanja langsung terhadap ketimpangan ekonomi wilayah di Provinsi Bengkulu diberikan sebagai berikut:

$$
\begin{aligned}
& \mathrm{KE} \quad=1.5518-0.0516 * \mathrm{BL} \\
& \mathrm{t} \text {-stat } \quad=(11.341) \quad(-3.2954) \\
& \text { Prob. }=(0.0000) \quad(0.0109) \\
& \mathrm{R}^{2} \quad=0.5758
\end{aligned}
$$

Dari persamaan tersebut diketahui nilai R-Squared model adalah sebesar 0,5758. Ini berarti variasi perubahan (naik atau turunnya) belanja langsung mempengaruhi ketimpangan ekonomi sebesar 57,58\%, sedangkan sisanya $(42,42 \%)$ dipengaruhi oleh variabel lain yang tidak dimasukkan dalam penelitian. Probabilitas $t$ sebesar 0.0109 $<0,05$ yang menunjukkan adanya pengaruh yang signifikan antara alokasi belanja langsung terhadap ketimpangan ekonomi wilayah di Provinsi Bengkulu.

\section{KESIMPULAN DAN SARAN}

\section{Kesimpulan}

1. Realisasi belanja langsung Provinsi Sumatera Utara lebih besar dari realisasi belanja langsung Provinsi Jambi dan Provinsi Bengkulu, namun laju pertumbuhan realisasi belanja langsung Provinsi Bengkulu lebih tinggi dibandingkan kedua provinsi lainnya.

2. Rata-rata Indeks Williamson untuk Provinsi Sumatera Utara sebesar 0.305, untuk Provinsi Jambi sebesar 0.04, dan untuk Provinsi Bengkulu sebesar 0.08. Berdasarkan hal tersebut dapat dikemukakan bahwa ketiga provinsi tersebut termasuk dalam provinsi dengan ketimpangan sedang.

3. Alokasi belanja langsung berpengaruh negatif signifikan terhadap ketimpangan ekonomi wilayah di Provinsi Sumatera Utara dan Bengkulu, tetapi tidak berpengaruh signifikan untuk Provinsi Jambi.

\section{Saran}

1. Pemerintah daerah sebagai pemegang kekuasaan tertinggi daerah seharusnya lebih meningkatkan alokasi belanja langsung mengingat belanja langsung berpengaruh terhadap perkembangan pembangunan ekonomi daerah.

2. Pemerintah daerah harusnya tidak membuat anggaran yang hanya berfokus pada pembangunan namun pemerintah daerah perlu menyeimbangkan alokasi dana untuk pemerataan. 
3. Dalam pengembangan pembangunan, pemerintah perlu perencanaan yang baik dan lebih meningkatkan pengembangan fasilitas umum mengingat minimnya pengembangan fasilitas umum yang dilakukan pemerintah daerah akhir-akhir ini.

4. Pemerintah perlu merencanakan peningkatan kualitas pengembangan investasi khususnya dalam bidang pendidikan, karena pengembangan pendidikan mempengaruhi kualitas sumber daya manusia yang ada didaerahnya.

\section{DAFTAR PUSTAKA}

Amir, Amri. 2007. Perekonomian Indonesia Dalam Perspektif Makro. Biografika. Bogor.

Anonim, 2007-2013. Produk Domestik Bruto Atas Harga Berlaku. BPS Pusat : www.BPS.go.id.

Anonim, 2007-2013. Realisasi APBD pemerintah daerah kabupaten/kota seluruh Indonesia: www.djpk.depkeu.go.id.Khalwaty, Tajul. 2000. Inflasi Dan Solusinya, PT.Gramedia Pustaka Utama, Jakarta.

Devita, A., Delis, A., \& Junaidi, J. (2014). Pengaruh Pendapatan Asli Daerah, Dana Alokasi Umum dan Jumlah Penduduk terhadap Belanja Daerah Kabupaten/Kota di Provinsi Jambi. Jurnal Perspektif Pembiayaan dan Pembangunan Daerah, 2(2), 63-70.

Mankiw, Gregory. 2007. Makro Ekonomi. Edisi Keenam. Jakarta : Erlangga.

Kuncoro, Mudjarad. 2007. Metode Kuantitatif Teori dan Aplikasi untuk Bisnis dan Ekonomi. Yogyakarta : UPP STIM YKPN.

Sukirno, Sadono. 2004. Makro Ekonomi Teori Pengantar. Edisi-3. PT. Raja Grafindo Persada. Jakarta.

Todaro, Michel P, Stephen C. Smith. 2000. Pembangunan Ekonomi 1. Edisi-5. Penerbit Erlangga. Jakarta.

Winarno, Wing Wahyu. 2007. Analisis Ekonometrika Dan Statistika Dengan Eviews Edisi Kedua. UPP STIM YKPN. Yogyakarta. 